Int. J. Electrochem. Sci., 13 (2018) 9273 - 9280

International Journal of

ELECTROCHEMICAL

SCIENCE

www.electrochemsci.org

Mini Review

\title{
Electrochemical Removal of NOx Using Oxide-Based Electrodes - A Review.
}

\author{
K. Kammer Hansen \\ Department of Energy Conversion and Storage \\ Technical University of Denmark - DK-4000, Roskilde, Denmark \\ *E-mail: kkha@dtu.dk
}

doi; $10.20964 / 2018.10 .09$

Received: 1 June 2018 / Accepted: 28 June 2018 / Published: 1 September 2018

Solid-state electrochemical reduction of NOx using oxide-based electrodes is reviewed. Different types of electrode and cell geometries have been used in the literature. Using simple ceramic point electrodes prepared using different materials; it has been shown that nitric oxide is reduced at different rates on different materials. For perovskites, it has been shown that the amount of trivalent transition metal and amount of oxide ion vacancies are important for the reduction of nitric oxide. The same applies to $\mathrm{Cu}$ and Ni-based $\mathrm{K}_{2} \mathrm{NiF}_{4}$ structures. For spinels, the pattern is less clear, but they are all able to reduce nitric oxide. Current densities are much higher when reducing nitrogen dioxide compared with nitric oxide on both perovskites and spinels. In gas mixtures containing nitric oxide and oxygen, the addition of $\mathrm{BaO}$ leads to fairly high conversion of nitric oxide into nitrogen. Finally, it has been shown that oxidizing nitric oxide to nitrogen dioxide before reducing to nitrogen is very beneficial, leading to current efficiencies of up to $65 \%$.

Keywords: Electrochemical deNOx, $\mathrm{NO}, \mathrm{NO}_{2}$, Oxides

\section{$\underline{\text { FULL TEXT }}$}

(C) 2018 The Authors. Published by ESG (www.electrochemsci.org). This article is an open access article distributed under the terms and conditions of the Creative Commons Attribution license (http://creativecommons.org/licenses/by/4.0/). 